\title{
Strategi Pengelolaan Paket Wisata Desa Karangtengah
}

\author{
Daniel Ezra Susanto ${ }^{1}$, Emanuel Mote ${ }^{1}$, Marcellino Yoga Wicaksana ${ }^{1}$, Christian Vernando ${ }^{1}$, Paulus Tegar Prabowo ${ }^{1}$, Yeriko Evandi Prasetya \\ Putra $^{1}$, Serafika Jiwa Patria ${ }^{1}$, Ni Putu Risma Pramesti Utami ${ }^{1}$, Veronika Sri Adiratna ${ }^{1}$, Vincentius Destian Viandaru ${ }^{1}$, Sendy Junedi ${ }^{1}$ \\ Universitas Atma Jaya Yogyakarta, Jalan Babarsari No. 43, Janti, Caturtunggal, Sleman ${ }^{1}$ \\ Email: sendy.junedi@uajy.ac.id
}

Received: June $11^{\text {th }} 2021$; Revised: -; Accepted for Publication November 29 ${ }^{\text {th }} 2021$; Published: November $29^{\text {th }} 2021$

\begin{abstract}
Karangtengah Village, Wonosari District, Gunung Kidul Regency is an agricultural village, but possesses cave natural resources that have been used as tourism. The Covid-19 pandemic reduces the number of tourists and left the village tourist sites abandoned. To assist the government in reviving the tourism sector and responding the physiological needs of community, this community service program is aimed to develop the potency of tourism in Karangtengah Village. The program was conducted by searching secondary data and processing it into plans that would be applied in Karangtengah Village. The programs to develop tourism sector are carried out by establishing tour packages including several tourist objects in the village and are equipped with open tourist car and also area to sale souvenir made by village residents. The tour packages provide benefits for tourists to get recommendations for tourist site in Karangtengah Village, convenient transportation that connect among the sites, proper travel schedules and easy ticket purchases. In addition, it can also increase the income of villagers in pandemic conditions. Nevertheless, the implementation of this idea must be carefully planned and receive support from various parties, including village officials, residents and the regional tourism office.
\end{abstract}

Keywords- Karangtengah Village, Tour Package, Tourism Car

\begin{abstract}
Abstrak- Desa Karangtengah, Kecamatan Wonosari, Kabupaten Gunung Kidul merupakan desa agraris namun memiliki sumber daya alam goa yang telah dimanfaatkan sebagai obyek wisata. Adanya pandemi Covid-19 menurunkan jumlah wisatawan dan menyebabkan terbengkalainya lokasi wisata desa. Untuk membantu pemerintah dalam menghidupkan kembali sektor pariwisata dan menjawab kebutuhan fisiolgis rekreasi masyarakat, maka program pengabdian masyarakat ini ditujukan untuk mengembangkan potensi wisata desa. Program dijalankan dengan mencari data sekunder dan mengolahnya menjadi upaya yang dapat diterapkan di Desa Karangtengah. Upaya pengembangan obyek wisata dilakukan dengan membuat paket wisata yang memasukan beberapa obyek wisata di desa dan dilengkapi dengan fasilitas kendaraan wisata terbuka serta area penjualan souvenir khas desa. Paket wisata memberikan keuntungan bagi wisatawan untuk mendapatkan rekomendasi obyek wisata Desa Karangtengah, fasilitas transport nyaman yang menghubungkan antar obyek wisata, jadwal perjalanan yang teratur dan pembelian tiket yang mudah. Selain itu juga memberikan peningkatan secara ekonomis bagi penduduk desa di kondisi pandemi. Meskipun demikian pelaksanaan upaya ini harus direncanakan dengan matang dan mendapat dukungan dari dari berbagai pihak baik aparat desa, penduduk desa dan dinas pariwisata daerah.
\end{abstract}

Kata kunci- Desa Karangtengah, Paket Wisata, Kendaraan Wisata

\section{Pendahuluan}

Kondisi pandemi Covid-19 menjadikan perekonomian Desa Karangtengah, Kecamatan Wonosari, Kabupaten Gunung Kidul tidak mengalami perkembangan, bahkan cenderung menurun [1]. Warga desa yang sebagian besar penduduknya sebagai petani tetap melalukan usaha di bidang pertanian untuk bertahan hidup dan mempertahankan perekonimian desa tetap berjalan [2]. Meskipun demikian, usaha di bidang pertanian tidak cukup untuk meningkatkan kembali perekonomian Desa Karangtengah. Diperlukan usaha untuk melihat potensi yang dimiliki oleh desa dan mencari jalan untuk pengembangannya. Potensi desa merupakan segenap sumber daya alam dan sumber daya manusia yang dimiliki desa sebagai modal dasar yang perlu dikelola dan dikembangkan bagi kelangsungan dan perkembangan desa.

Desa Karangtengah memiliki sumber daya alam berupa goa yang cukup banyak yaitu Goa Pari, Goa Suci, Goa Bening, serta sumber air bernama sumber Mbener, Mbacin, dan juga bumi perkemahan Tegal Arum. Seluruh sember daya alam ini telah dikembangkan oleh penduduk desa sebagai obyek wisata alam yang beberapa diantaranya dilengkapi dengan fasilitas dan kegiatan rekreasi, sehingga obyek wisata memberikan 2 manfaat dari segi alam dan segi kegiatan rekreasi bagi wisatawan [3]. Fasilitas rekreasi yang dibangun di area obyek wisata adalah kolam renang dan permainan air yang menambah daya tarik wisata di Desa Karangtengah. Pemanfaatan sumber daya alam desa tersebut sebagai obyek wisata telah membuka lapangan pekerjaan bagi penduduk desa dan mengaktifkan kegiatan perekonomian desa.

Adanya pandemi Covid-19 menjadikan sektor pariwisata menjadi menurun di berbagai tempat di Indonesia termasuk di Desa Karangtengah. Kondisi berkurangnya wisatawan yang datang di Desa Karangtengah, diikuti dengan respon penduduk desa yang tidak lagi mampu menjaga kondisi tempat wisata, sehingga area wisata menjadi terbengkalai dan makin menurunkan minat wisatawan yang hendak datang. Lamanya masa pandemi Covid-19 secara tidak langsung akan memberikan kejenuhan masyakarat yang tidak memiliki akses luas untuk berinteraksi sosial. Kondisi ini menjadikan kelelahan mental yang dialami oleh setiap orang di berbagai kalangan usia. Kebutuhan konsumen pariwisata ini termasuk dalam kategori kebutuhan fisiologis rekreasi yang tidak hanya tinggi pada masa sebelum pandemi tapi juga selama pandemi, meskipun kebutuhan keamanan juga merupakan kebutuhan konsumen yang sama tingginya [4] [5].

Menanggapi kebutuhan fisiologis tersebut, pariwisata menjadi solusi penting bagi masyarakat. Saat ini pemerintah Indonesia melalui Kementerian Pariwisata dan Ekonomi Kreatif Republik Indonesia telah berupaya untuk menghidupkan kembali bidang pariwisata dengan menerapkan sertifikasi pariwisata bernama CHSE kepada pelaku usaha wisata. Sertifikat CHSE merupakan sertifikat 
yang diberikan kepada pelaku usaha pariwisata yang memenuhi persyaratan penerapan protokol kesehatan yang berbasis pada Cleanliness (Kebersihan), Health (Kesehatan), Safety (Keamanan), dan Environment Sustainability (Kelestarian Lingkungan). Dengan adanya sertifikat ini obyek wisata dinyatakan layak bagi wisatawan di masa pandemi [6].

Menanggapi kebutuhan pariwisata dan juga upaya pemerintah untuk menghidupkannya, maka program pengabdian masyarakat ini diarahkan pada penyampaian ide pengembangan obyek wisata di Desa Karangtengah. Pengembangan obyek wisata dilakukan dengan mengorganisir beberapa obyek wisata yan sudah ada dalam bentuk paket wisata. Selain itu juga ada pembuatan kendaraan wisata yang menghubungkan beberapa obyek wisata yang termasuk dalam paket tersebut. Upaya pengembangan juga dilakukan dengan membuat area penjualan produk khas desa berbahan dasar belalang. Adanya paket wisata memberikan keuntungan bagi wisatawan untuk mendapatkan rekomendasi obyek wisata Desa Karangtengah, fasilitas transport nyaman yang menghubungkan antar obyek wisata, jadwal perjalanan yang teratur dan pembelian tiket yang mudah. Program pembuatan paket wisata ini akan efektif jika didukung oleh promosi yang tepat. Media sosial yang semakin berkembang di berbagai kalangan usia dan tempat menjadi pilihan media yang efektif untuk mensosialisasikan dan memperjualbelikan produk termasuk paket wisata.

Pengembangan obyek wisata Desa Karangtengah menjadi paket wisata yang didukung oleh inovasi kendaraan wisata dan penjualan makanan khas belalang merupakan upaya yang tergolong baru untuk pengembangan pariwisata di Desa Karangtengah. Dengan upaya ini diharapkan dapat memberikan semangat kepada penduduk desa untuk menjaga potensi sumber daya alam yang sudah ada dan mengembangkannya. Pada akhirnya upaya ini diharapkan tidak hanya meningkatkan perekonomian desa tetapi juga dapat mengatasi kejenuhan masyarakat di masa pandemik Covid-19. Program pengabdian masyarakat ini dilaksanakan dengan menyampaikan ide dan upaya kepada masyakarat Desa Karangtengah melalui pembuatan video dan ebook yang dapat diakses melalui internet.

\section{Metode Pengabdian}

Program pengabdian masyarakat di Desa Karangtengah, Kecamatan Wonosari, Kabupaten Gunungkidul, dilakukan melalui program kuliah kerja nyata (KKN) dengan metode KKN SOCIETY 5.0 secara daring dan tidak dilakukan penerjunan langsung ke lapangan. Pencarian data terkait desa dilakukan melalui internet dan beberapa penulis datang ke desa untuk melihat keadaan sekitar tanpa berinteraksi dengan masyarakat Desa Karangtengah. Semua bentuk diskusi dan bimbingan oleh Dosen pembimbing KKN menggunakan media komunikasi Microsoft Teams dan Whatsapps.

Data yang diperlukan pada program pengabdian adalah data sekunder. Data sekunder adalah data yang diperoleh dari hasil penelitian atau pengamatan peneliti lain. Pengumpulan data sekunder dilakukan melalui internet dengan mengakses website resmi desa dan sumber lain yang valid. Setelah mengumpulkan sekunder, dilakukan analisa data, membuat daftar potensi desa dan permasalahan desa, kemudian menentukan target potensi desa yang akan dikembangkan.

Dari daftar potensi desa yang sudah dibuat, dilakukan pemilihan potensi desa yang paling berdampak bagi perkembangan desa dan sekaligus yang paling bermanfaat bagi masyarakat luas jika dikembangkan. Setelah dilakukan pemilihan target potensi desa kemudian dicari ide-ide yang belum pernah dilakukan oleh desa. Ide tersebut digali dengan melihat referensi yang ada di internet dan pertimbanagn kondisi sebenarnya saat diaplikasikan di lapangan. Ide pengembangan potensi desa kemudian dituangkan dalam bentuk ebook dan video dengan tahapan pembuatan dijelaskan seperti di bawah.

\section{A. Pembuatan Ebook}

Pembuatan $e$-book dilakukan melalui sebuah website Canva (www.canva.com). Pembuatan e-book bertujuan untuk memudahkan penyampaian informasi terkait strategi penerapa paket wisata dan promosinya melalui media sosial. Tahapan pembuatan ebook desa wisata dilakukan dengan menyusun materi yang diperoleh dari referensi di internet, kemudian menetapkan template ebook yang dimodifkasi dengan gambar.

\section{B. Pembuatan Video}

Pembuatan video animasi desa wisata menggunakan aplikasi Animaker dari website www.animaker.com dengan isi yang sama dengan ebook. Tahapan pembuatan video animasi desa wisata dilakukan dengan memilih template, lalu ditambahkan tulisan, animasi bergerak, gambar maupun foto. Setelah itu, dilakukan pemilihan musik dan dimasukan ke dalam video animasi. Proses terakhir adalah editing waktu tiap scene disesuaikan dengan banyaknya tulisan dan komponen di dalam scene tersebut. Pembuatan video animasi ini bertujuan supaya masyarakat dapat membaca dan mengerti isi program dengan lebih detail.

Pada akhir program, dilakukan pelaporan secara tertulis ke LPPM Universitas Atma Jaya Yogyakarta (UAJY) dan penulisan naskah jurnal. Laporan kepada LPPM ditujukan untuk kalangan internal universitas, sedangkan jurnal untuk informasi bagi kalangan akademisi dan masyarakat di luar universitas.

\section{HASIL DAN PEMBAHAAN}

Desa Karangtengah terletak di Kecamatan Wonosari, Kabupaten Gunungkidul, Daerah Istimewa Yogyakarta dengan luas 50,461,65 Ha dan jumlah penduduknya 4.465 laki-laki dan 4.391 perempuan [7]. Mayoritas penduduk Desa Karangtengah memiliki mata pencaharian bertani dan berdagang sehingga corak desa ini adalah agraris dan sebagian besar wilayah desa digunakan sebagai sawah [8].

Meskipun sebagian besar sebagai petani dan pedagang, penduduk desa ada yang bekerja di sektor pariwisata dengan mengelola obyek wisata Goa Pari, Goa Suci, Goa Bening, Sumber Mbener, Sumber Mbacin dan Tegalarum Adventure Park [9]. Tempat wisata di Desa Karangtengah memiliki 
daya tarik alam yang menarik dan banyak dicari oleh keluarga yang ingin berlibur dan juga sebagai tujuan wisata pendidikan bagi siswa sekolah [10].

Dikarenakan pandemi Covid-19, obyek wisata di Desa Karangtengah mengalami penurunan wisatawan, yang mengakibatkan kondisi obyek wisata terbengkalai karena tidak ada pemasukan finansial. Untuk bertahan dan bertumbuh di sektor pariwisata, pelaku usaha wisata termasuk desa harus memberikan nilai tambah dengan memberikan informasi dan fasilitas yang dapat diakses oleh wisawatan dengan mudah [11]. Mengingat lokasi obyek wisata Desa Karangtengah yang berdekatan satu dengan yang lain maka dapat dilakukan pengembangan dengan membuat paket wisata yang akan mempermudah wisatawan mengakses obyek wisata. Penyampaian informasi paket wisata kepada konsumen pariwisata dapat dilakukan dengan mencari media yang mudah diakses dan disukai oleh masyarakat. Di masa pembatasan sosial saat ini, media sosial seperti Facebook, Instagram, ataupun Blog merupakan media yang sering diakses oleh masyarakat berbagai kalangan untuk berkomunikasi, promosi, mendapatkan informasi dan bahkan berjual beli. Selain publikasi juga perlu dilakukan peningkatan pelayanan wisata berupa pengadaan kendaraan wisata yang menghubungkan lokasi obyek wisata satu dengan yang lain. Kendaraan wisata berupa kendaraan bermesin terbuka yang dapat diisi oleh 5 hingga 8 orang. Kendaraan dengan konsep terbuka memungkinkan wisatawan mengakses obyek wisata satu dengan yang lain dan menikmati pemandangan sepanjang jalan (Gambar 1) yang masih alami.

Area wisata juga dapat digunakan untuk area penjualan souvernir produk makanan dari bahan baku belalang hasil budidaya belalang dari penduduk Desa Karangtengah. Untuk meningkatkan penjualan makanan khas ini, area kuliner produk belalang akan dimasukkan ke area obyek wisata yang termasuk di paket wisata. Adanya paket wisata, kendaraan wisata, dan area kuliner tidak hanya memberikan manfaat bagi wisatawan tetapi juga dapat membuka lapangan pekerjaan baru seperti pemandu wisata, pengemudi kendaraan, dan manajemen paket wisata bagi penduduk Desa Karangtengah.

Paket wisata Desa Karangtengah dibuat menjadi dua yaitu paket hemat dan paket utama dengan perbedaan pada jumlah obyek wisata yang dapat dikunjungi, rute dan biaya paket wisata.

1. Paket hemat

Obyek wisata: Tegalarum Adventure Park, dan Goa Pari atau Goa Bening

2. Paket utama

Obyek wisata: Tegalarum Adventure Park, Goa Pari/Goa Bening dan Kolam Renang Tirtaria.

Mengingat jumlah obyek wisata yang dapat dikunjungi maka biaya paket wisata utama lebih mahal dibanding paket hemat. Tiket paket wisata dapat diperoleh secara online melalui website desa dan juga dapat langsung dibeli di obyek wisata Tegalarum Adventure Park sebagai area pertama mulainya rute paket wisata.

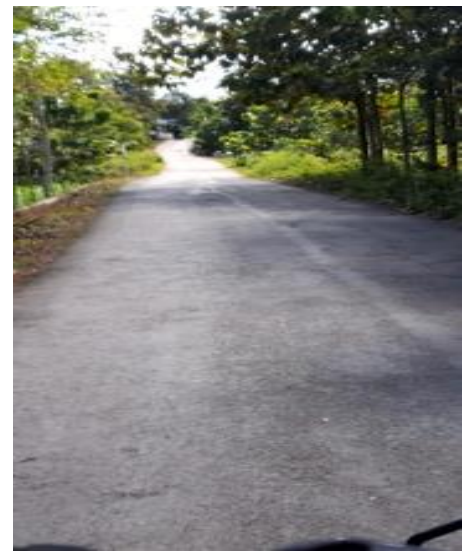

Gambar 1. Kondisi Jalan dan Pemandangan yang Menghubungkan Antar Obyek Wisata.

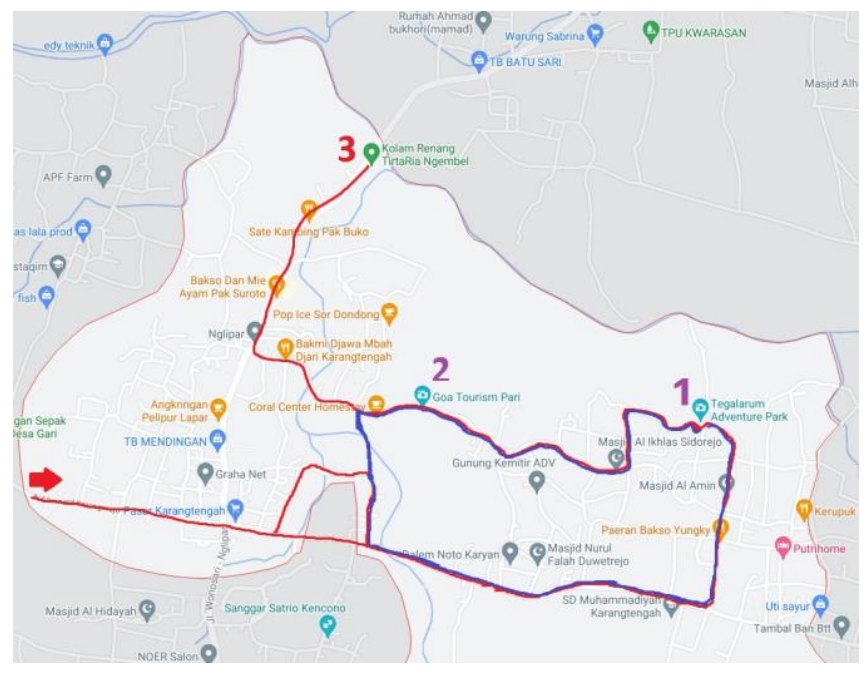

Gambar.2 Rute Paket Wisata Utama dan Paket Wisata Hemat. Paket utama (merah) melalui Tegalarum Adventure Park (1), Goa Pari atau Goa Bening (2), Kolam Renang Tirtaria (3). Paket hemat (biru) melalui obyek wisata Tegalarum Adventure Park (1) dan Goa Pari atau Goa Bening (2).

Rute kedua paket wisata dimulai dari obyek wisata Tegalarum Adventure Park, dimana wisatawan dapat memarkirkan kendaraan pribadi di area parkir yang cukup luas. Di area tersebut juga dibuat tempat pembelian tiket paket wisata dan halte untuk kendaraan wisata. Untuk rute paket utama, kendaraan wisata akan bergerak dari Tegalarum Adventure Park menuju ke Goa Pari/ Goa Bening dilanjutkan ke Kolam Renang Tirtaria (Gambar 2). Di akhir rute wisata, wisatawan akan kembali melalui jalan yang sama dari Kolam Renang Tirtaria menuju Tegalarum Adventure Park. 
Rute paket hemat berawal dari dari Tegalarum Adventure Park menuju ke Goa pari/ Goa Bening, kemudian kembali ke Tegalarum Adventure Park. Adanya voucher pembelian souvenir produk belalang pada paket wisata utama memberikan stimulus untuk wisatawan mencoba produk khas desa Karangtengah dan meningkatkan pembelian produk desa.

Konsep paket wisata ini akan memberikan kemudahan wisatawan untuk mengakses obyek wisata desa dengan fasilitas transportasi yang nyaman dan jadwal perjalanan yang teratur serta pembelian tiket yang mudah. Penyampaian konsep paket wisata secara detail telah dilakukan dalam bentuk ebook dan video yang dapat diakses oleh masyaraat melalui internet. Mengingat upaya pembuatan paket wisata ini cukup kompleks maka realisasinya membutuhkan perencanaan dan dukungan dari berbagai pihak baik aparat desa, penduduk desa dan Dinas Pariwisata daerah.

\section{KESIMPULAN}

Potensi obyek wisata di Desa Karangtengah telah dikembangkan dengan baik oleh penduduk Desa, namun adanya pandemi Covid-19 mengurangi konsumen pariwisata dan menyebabkan terbengkalainya kondisi obyek wisata. Untuk membantu pemerintah menghidupkan kembali sektor pariwisata sebagai solusi kebutuhan fisiologis rekreasi masyarakat, maka dilakukan upaya pengembangan obyek wisata dengan pengadaan paket wisata yang dilengkapi kendaraan wisata terbuka dan area souvernir khas desa. Pembuatan paket wisata memberikan keuntungan bagi wisatawan untuk mendapatkan rekomendasi obyek wisata Desa Karangtengah, fasilitas transport nyaman yang menghubungkan antar obyek wisata, jadwal perjalanan yang teratur dan pembelian tiket yang mudah. Selain itu juga memberikan keuntunga ekonomis bagi desa dan penduduk desa selaku pelaku usaha. Meskipun demikian pelaksanaan upaya ini harus direncanakan dengan matang dan mendapat dukungan dari dari berbagai pihak baik aparat desa, penduduk desa dan Dinas Pariwisata daerah.

\section{UCAPAN TERIMAKASIH}

Penulis mengucapkan terimakasih kepada Lembaga Penelitian dan Pengabdian Masyarakat (LPPM) Universitas Atma Jaya Yogyakarta yang telah menyelenggarakan Kuliah Kerja Nyata (KKN) Periode 79 yang dilakukan secara daring.

\section{DAFTAR PUSTAKA}

[1] I. R. Kandar, "Kondisi Sosisal Ekonomi Masyarakat Gunungkidul Sebelum Pelaksanaan Revolusi Hijau," Universitas Negeri Yogyakarta, 2014.

[2] U. Suchaini, "Memperkuat Desa di Masa Pandemi," 2020. https://news.detik.com/kolom/d-5006896/memperkuat-desa-dimasa-pandemi (accessed May 29, 2021).

[3] S. I. P. Barus, P. Patana, and Y. Afiffudin, "Analisis Potensi Obyek Wisata dan Kesiapan Masyarakat dalam Pengembangan Desa Wisata Berbasis Masyarakat di Kawasan Danau Linting Kabupaten Deli Serdang," 2013, [Online]. Available: https://media.neliti.com/media/publications/157779-ID-analisispotensi-obyek-wisata-dan-kesiap.pdf.

[4] S. Nugroho, Perilaku Konsumen. Jakarta: Pranamedia Group,
2003

[5] W. Suprihatin, "Analisis Perilaku Konsumen Wisatawan Era Pandemi Covid-19 (Studi Kasus Pariwisata di Nusa Tenggara Barat)," vol. 1, no. 1, pp. 55-66, 2020.

[6] A. D. T., "Upaya Pemulihan Industri Pariwisata Dalam Situasi Pandemi Covid -19," vol. 8, no. 1, pp. 22-31, 2021.

[7] Sistem Informasi Desa Karangtengah, "Kalurahan Karangtengah Kepanewon Wonosari Kabupaten Gunungkidul," 2020. https://www.karangtengah-wonosari.desa.id/first (accessed May 23, 2021).

[8] Sistem Informasi Desa Karangtengah, "Daftar Perangkat Desa Karangtengah," $2017 . \quad$ https://www.karangtengahwonosari.desa.id/first/artikel/109-DAFTAR-PERANGKATDESA-KARANGTENGAH (accessed May 23, 2021).

[9] A. Nugroho, "Pesona Keindahan Wisata Goa Pari di Wonosari Gunung Kidul Yogyakarta," 2021. https://ihategreenjello.com/pesona-keindahan-wisata-goa-pari-di/ (accessed May 23, 2021).

[10] A. Nugroho, "Pesona Keindahan Wisata Goa Bening di Wonosari Gunung Kidul Yogyakarta," 2021. https://ihategreenjello.com/pesona-keindahan-wisata-goa-beningdi/ (accessed May 23, 2021).

[11] J. Waskita and P. M. Tri, "Strategi Pemasaran Pariwisata Dalam Rangka Meningkatkan Pendapatan Asli Daerah," 2008, [Online]. Available: https://media.neliti.com/media/publications/241749strategi-pemasaran-pariwisata-dalam-rang-8a912401.pdf.

\section{PENULIS}

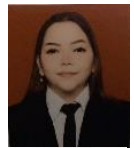

Serafika Jiwa Patria, prodi Ilmu Hukum, Fakultas Hukum, Universitas Atma Jaya Yogyakarta.

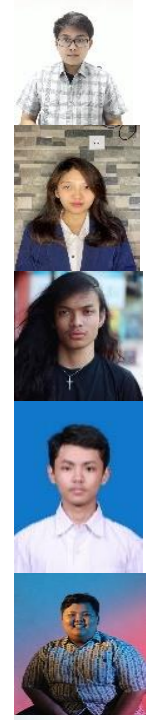

Daniel Ezra Susanto, prodi Akuntasi, Fakultas Bisnis dan Ekonomi, Universitas Atma Jaya Yogyakarta.

Ni Putu Risma Pramesti Utami, prodi Sistem Informasi, Fakultas Teknologi Industri, Universitas Atma Jaya Yogyakarta.

Paulus Tegar Prabowo, prodi Teknik Industri, Fakultas Teknologi Industri, Universitas Atma Jaya Yogyakarta.

Yeriko Evandi Prasetya Putra, prodi Teknik Sipil, Fakultas Teknik Sipil, Universitas Atma Jaya Yogykarta.

Marcellino Yoga Wicaksana, prodi Ilmu Komunikasi, Fakultas Ilmu Sosial. Universitas Atma Jaya Yogyakarta.

Vincentius Destian Viandaru, prodi Ilmu Komunikasi, Fakultas Ilmu Sosial, Universitas Atma Jaya Yogyakarta.

Veronika Sri Adiratna, prodi Teknik Industri, Fakultas Teknologi Industri, Universitas Atma Jaya Yogyakarta.

Christian Vernando, prodi Teknik Informatika, Fakultas Teknik, Universitas Atma Jaya Yogyakarta. 
Emanuel Mote L, prodi Ekonomi Pembangunan, Fakultas Ekonomi, Universitas Atma Jaya Yogyakarta.

Sendy Junedi

Program Studi Biologi, Fakultas Teknobiologi,

Universitas Atma Jaya Yogyakarta 